\title{
Phenotypic Characterization of Faba Bean (Vicia faba L.) Landraces Grown in Palestine
}

\author{
Talal Al Barri ${ }^{1} \&$ Munqez J Y Shtaya ${ }^{1}$ \\ ${ }^{1}$ Department of Plant Production and Protection, Faculty of Agriculture, An-Najah National University, Nablus, \\ Palestine \\ Correspondence: Munqez J Y Shtaya, Department of Plant Production and Protection, Faculty of Agriculture, \\ An-Najah National University, Nablus, Palestine. E-mail: mshtaya@najah.edu
}

Received: November 23, 2012 Accepted: December 10, 2012 Online Published: January 15, 2013

doi:10.5539/jas.v5n2p110

URL: http://dx.doi.org/10.5539/jas.v5n2p110

\begin{abstract}
This study was conducted to investigate the morphological and agronomical variations among nineteen Palestinian faba bean (Vicia faba L.) landraces. And analyze their traits including: days to flowering, days to fruit setting, plant height, number of branches on main stem, lowest pod height, pod length, pod width, number of pods per plant, number of seeds per pod, 100-seed weight and total pod weight per plant were studied. Significant differences were observed among genotypes for all characters. The nineteen faba bean lines were clustered into four groups based on six morphological and agronomic traits (pod length, pod width, number of pods per plant, number of seeds per pod, 100-seed weight and total pod weight per plant). Several genotypes could be considered as promising material for pod production. Further studies are needed to compare the productivity of these genotypes with international varieties and identify QTL controlling the productivity of these genotypes and to study the variation between and within these genotypes at the molecular level.
\end{abstract}

Keywords: faba bean, landraces, phenotypic characterization, Vicia faba

\section{Introduction}

Faba bean (Vicia faba L.) is an important winter legume crop originated in between the oriental Mediterranean countries and Afghanistan (Cubero, 1974). The main faba bean producers are China (1.65 Mt), Ethiopia (0.61 Mt), France (0.44 Mt), Egypt (0.29 Mt) and Australia (0.19 Mt) (FAOSTAT, 2009). Faba bean is a valuable protein-rich food that provides a large sector of the human populations in developing countries with a cheap protein source thus partly compensating for the large deficiency in animal protein sources.

In developed countries faba bean provides an alternative to soybean meal for animal feed, this being particularly important in the more industrialized countries (Gous, 2011). Faba bean plays a significant role in improving the productivity of the soil in the cereal-based rotations where it serves as a break crop; yields of cereal crops following faba bean are improved and needs for nitrogen fertilizer applications are reduced. Studies on the fixation of atmospheric nitrogen through symbiosis in organic farming shown that faba bean surpasses peas in the amount of nitrogen fixed (Reiter et al., 2002).

Faba bean is one of the essential legume crops grown in Palestine mainly under rain fed conditions. The annual production of faba bean in Palestine is very low and varies from year to year and from location to location, with a total production of about 339.5 tons cultivated on 399 ha (PCBS, 2008). Many Palestinian faba bean farmers grow landraces meanwhile others grow imported cultivars because of their high productivity (Ministry of Agriculture, personal communication). These landraces are valuable source of genetic variation and may possess some interesting characteristics such as small size of pods and adaptation to prevailing local environmental conditions.

In Palestine, faba bean landraces have not been genetically evaluated. Characterization of the genetic variation in the available germplasm is important for further improvement of crop yield and to impart resistance to biotic and abiotic stresses. Using phenotypic data in cultivar identification, study genetic diversity of plants was previously scored for many plants (Ceccarelli et al., 1987; Polignano et al., 2008; Salem et al., 2008).

The main objectives of this study were to investigate the morphological, agronomical variations among nineteen Palestinian faba bean (Vicia faba L.) landraces. 


\section{Materials and Methods}

\subsection{Source of Seeds}

Seeds of nineteen faba bean landraces collected from farmers in different regions in Palestine (Table 1) were used in this study.

Table 1. Faba bean (Vicia faba L.) landraces collected from different regions in Palestine

\begin{tabular}{cccccc}
\hline Accession & Collection site & Province & Accession & Collection site & Province \\
\hline VF-1 & Al-Ras & Qalqilya & VF-11 & Shwakeh & Tulkarm \\
VF-2 & AlZababdeh & Jenin & VF-12 & Tubas & Tubas \\
VF-3 & Emateen & Qalqilya & VF-13 & Tubas & Tubas \\
VF-4 & Bet-Iba & Nablus & VF-14 & Tulkarm & Tulkarm \\
VF-5 & Beta & Nablus & VF-15 & Azoun & Qalqilua \\
VF-6 & Tayaseer & Tubas & VF-16 & Anabta & Tulkarm \\
VF-7 & Jayous & Qalqilya & VF-17 & Aean-Albeda & Tubas \\
VF-8 & Senjel & Ramallah & VF-18 & Nablus & Nablus \\
VF-9 & Qabatya & Jenin & VF-19 & Ne'eleen & Ramallah \\
VF-10 & Selet-Aldaher & Jenin & & & \\
\hline
\end{tabular}

\subsection{Experimental Site}

Field experiment was conducted at the experimental farm of the Faculty of Agriculture, An-Najah National University, Tulkarm (Khadouri), Palestine $\left(32.31519^{\circ} \mathrm{N}\right.$ and $35.02033^{\circ} \mathrm{W}$ and altitude of $75 \mathrm{~m}$ ) during the 2009/2010 growing season in a heavy clay soil. All accessions were sown at the $1^{\text {st }}$ of December 2009 in three complete randomized blocks. Each accession was represented by 10-15 seeds in a single row, $1 \mathrm{~m}$ long per replicate. Ten seedlings remained after removing the excess seedlings in every row.

\subsection{Cultural Practices}

The experimental open field was plowed two times before planting. All accessions were sown in a clay loamy soil. Protection against aphids was made by spraying "Berimor, a.i." at a rate of $40 \mathrm{~g}$ per $20 \mathrm{~L}$. Plants were not protected against foliar fungal diseases. Hand weeding between and within rows were done and continued throughout the growing season, no fertilizers or supplementary irrigation where used during the growing season.

\subsection{Data Collection}

During the growth season and before maturity, the following data were recorded:

1. Days to flowering: number of days from planting the seeds until $90 \%$ of the plants per accession were flowering.

2. Days to fruit setting: number of days from planting the seeds until $90 \%$ of the plants per accession were setting fruits.

At maturity stage (green pods), the following measurements were taken from each line by harvesting five plants from the centre of the row:

1. Plant height: from ground level to the plant shoot tip.

2. Number of branches on the main stem: from basal and mediated nodes.

3. Lowest pod height: from ground level to the first pod on the plant.

4. Pod length: for five random pods, measured as the distance between the edges of pod.

5. Pod width: was measured for five random pods at the center of pod_using a caliper.

6. Number of pods per plant: was measured as the average of five plants.

7. Number of seeds per pod: was counted for ten random pods. 
8. 100 -seed fresh weight: determined by mixing the whole samples, then 100 seeds were randomly counted and weighted.

9. Total pod weight per plant: was measured as the average of five plants.

For the statistical analysis, the average of the five harvested plants was used for each treat.

\subsection{Statistical Analysis}

Analysis of variance (ANOVA) was conducted using PROC GLM of SAS/STAT software (version 9.0 for Windows) (SAS institute, 2002). Multiple comparisons among pairs of lines were made by the REGWQ-test. Cluster analysis was performed using the complete-linkage method.

\section{Results and Discussion}

\subsection{Days to Flowering}

Significant variation in days to flowering between landraces was observed (Table 2). The majority of the collection (84\%) presented early flowering genotypes (from 60-63 days after planting). Three accessions (VF-14, VF-10 and VF-12) showed significantly longer days to flowering (76.7, 70.0 and 66.7 respectively), and differed from all the other genotypes, $(\mathrm{P}<0.05)$. These results were in agreement with Suso et al. (1993), who found significant difference in days to flowering among Spanish faba bean cultivars. Other studies showed that faba bean genotypes had longer time to flowering when grown under irrigation condition than those grown under rainfed conditions (Della, 1988).

Table 2. Morphological characters of nineteen faba bean landraces grown during 2009/2010 growing season

\begin{tabular}{|c|c|c|c|c|c|}
\hline Accession & $\overline{D F}$ & DFS & $\mathrm{PH}$ & LPH & NBMS \\
\hline VF-1 & $62.0^{\mathrm{cd} *}$ & $70.0^{\mathrm{cd} *}$ & $70.0^{\text {efg* }}$ & $25.00^{\text {cde* }^{*}}$ & $0.67^{\mathrm{fgh}^{x}}$ \\
\hline VF-2 & $63.3^{\mathrm{cd}}$ & $70.0^{\mathrm{cd}}$ & $78.3^{\mathrm{cd}}$ & $16.67^{\mathrm{fgh}}$ & $3.67^{\mathrm{bc}}$ \\
\hline VF-3 & $60.0^{\mathrm{d}}$ & $70.0^{\mathrm{cd}}$ & $75.0^{\mathrm{def}}$ & $13.33^{\mathrm{hi}}$ & $5.00^{\mathrm{bc}}$ \\
\hline VF-4 & $60.0^{\mathrm{d}}$ & $66.7^{\mathrm{d}}$ & $68.3^{\mathrm{fgh}}$ & $11.67^{\mathrm{hij}}$ & $0.33^{\mathrm{gh}}$ \\
\hline VF-5 & $60.0^{\mathrm{d}}$ & $66.7^{\mathrm{d}}$ & $78.3^{\mathrm{cd}}$ & $28.33^{c}$ & $3.00^{\text {cde }}$ \\
\hline VF-6 & $60.0^{\mathrm{d}}$ & $70.0^{\text {cd }}$ & $61.7^{\mathrm{h}}$ & $10.00^{\mathrm{ij}}$ & $2.00^{\mathrm{def}}$ \\
\hline VF-7 & $60.0^{\mathrm{d}}$ & $66.7^{\mathrm{d}}$ & $61.7^{\mathrm{h}}$ & $11.67^{\mathrm{hij}}$ & $0.00^{\mathrm{h}}$ \\
\hline VF-8 & $60.0^{\mathrm{d}}$ & $70.0^{\mathrm{cd}}$ & $96.7^{\mathrm{a}}$ & $15.00^{\text {hig }}$ & $2.33^{\text {cde }}$ \\
\hline VF-9 & $60.0^{\mathrm{d}}$ & $73.3^{\mathrm{bcd}}$ & $65.0^{\mathrm{gh}}$ & $26.67^{\mathrm{cd}}$ & $0.67^{\mathrm{fgh}}$ \\
\hline VF-10 & $70.0^{\mathrm{b}}$ & $80.0^{\mathrm{b}}$ & $78.3^{\mathrm{cd}}$ & $41.67^{b}$ & $2.67^{\text {cde }}$ \\
\hline VF-11 & $60.0^{\mathrm{d}}$ & $76.7^{\mathrm{bc}}$ & $76.7^{\mathrm{de}}$ & $6.67^{\mathrm{j}}$ & $2.33^{\text {cde }}$ \\
\hline VF-12 & $66.7^{\mathrm{bc}}$ & $80.0^{\mathrm{b}}$ & $96.7^{\mathrm{a}}$ & $28.33^{\mathrm{c}}$ & $0.33^{\text {gh }}$ \\
\hline VF-13 & $63.3^{\mathrm{cd}}$ & $76.7^{\mathrm{bc}}$ & $96.7^{\mathrm{a}}$ & $13.33^{\mathrm{hi}}$ & $6.33^{\mathrm{a}}$ \\
\hline VF-14 & $76.7^{\mathrm{a}}$ & $93.3^{\mathrm{a}}$ & $85.0^{\mathrm{bc}}$ & $41.67^{\mathrm{b}}$ & $5.33^{\mathrm{a}}$ \\
\hline VF-15 & $60.0^{\mathrm{d}}$ & $70.0^{\mathrm{cd}}$ & $70.0^{\mathrm{efg}}$ & $13.33^{\mathrm{hi}}$ & $6.33^{\mathrm{a}}$ \\
\hline VF-16 & $60.0^{\mathrm{d}}$ & $70.0^{\text {cd }}$ & $70.0^{\mathrm{efg}}$ & $20.00^{\mathrm{efg}}$ & $3.33^{\mathrm{cd}}$ \\
\hline VF-17 & $60.0^{\mathrm{d}}$ & $66.7^{\mathrm{d}}$ & $80.0^{\mathrm{cd}}$ & $21.67^{\mathrm{def}}$ & $1.67^{\mathrm{efg}}$ \\
\hline VF-18 & $60.0^{\mathrm{d}}$ & $66.7^{\mathrm{d}}$ & $63.3^{\mathrm{gh}}$ & $15.00^{\text {hig }}$ & $2.00^{\mathrm{def}}$ \\
\hline VF-19 & $60.0^{\mathrm{d}}$ & $70.0^{\mathrm{cd}}$ & $88.3^{\mathrm{b}}$ & $58.33^{\mathrm{a}}$ & $0.67^{\text {fgh }}$ \\
\hline
\end{tabular}

* Means in the same column with similar letters are not significantly different (REGWQ, P $\geq 0.05$ ).

DF: Days to flowering, DFS: days to fruit setting, PH: plant height, LPH: lowest pod height, NBMS: no. of branches on main stem. 


\subsection{Days to Fruit Setting}

Significant variation in days to fruit setting was observed (Table 2). Accession VF-14 scored the longest days to fruit setting when compared to the other genotype. The average period needed to fruit setting was 72 days. These results were in agreement with Al- Refaee et al. (2004), who found that the date of fruit setting among faba bean genotypes varied significantly. Fruit setting is affected by genetic make up and environmental factors. The effect of genetic make up is shown in the differences between genotypes used in the current study. Nanda et al. (1988) reported that significant differences were observed for days to pod formation between 25 faba bean genotypes grown under irrigation conditions. The environmental factors affecting fruit setting are mainly related to change in temperature and rainfall.

\subsection{Plant Height}

Significant variation on plant height was observed (Table 2). Accessions VF-8, VF-12 and VF-13 were significantly the tallest $(96.67 \mathrm{~cm})$ (Table 2) while, VF-6 and VF-7 were the shortest plants $(61.67 \mathrm{~cm})$. These results were in agreement with Della (1988) who found that plant height of faba bean genotypes varied significantly under rainfed conditions. Suso et al. (1993) reported that plant height was an important trait discriminating among different geographic regions

\subsection{Lowest Pod Height}

Significant variation in the lowest pod height was observed among accessions (Table 2). Accession VF-11 showed the lowest average pod height and VF-19 with the highest value (6.67 and $58.33 \mathrm{~cm}$ respectively). These results are in agreement with the results of Della (1988), who reported that faba bean genotypes varied significantly in different environmental conditions for the lowest pod height. Terzopoulos et al. (2003) found that the lowest pod height ranged from 2 to $24 \mathrm{~cm}$ among 55 faba bean genotypes. Suso et al. (1993) reported that late flowering faba bean genotypes gave a high position of the lowest pod-bearing nodes, while plants early in flowering gave low position of the lowest pod bearing node corresponding to the region grown in.

\subsection{Number of Branches on Main Stem}

Significant variation was observed in number of branches on main stem (Table 2). Accessions VF-14, VF-13 and VF-15 gave the highest number of primary branches per plant (5.3, 6.3 and 6.3 branches per plant respectively), while accession VF-7 gave the lowest number of primary branches per plant (zero branch per plant). These results are in agreement with Silim and Saxena (1992), who found that genotypes were different on the number of branches. The differences in the present study may be due to the high temperatures prevailed at Tulkarm during the early growing stage.

\subsection{Pod Length}

Significant variation in pod length was observed (Table 3). Accessions VF-4 and VF-10 showed the highest pod length (11.17 and $11.47, \mathrm{~cm}$ respectively), while VF-2 genotype gave the lowest pod length $(4.47 \mathrm{~cm})$. These results are in agreement with those reported by Suso et al. (1993) who found that genotypes varied significantly in pod length. Li-juan et al. (1993) reported, by analyzing agronomic and yield traits for 1500 germplasm from different provinces in China, that pod lengths were less than $10 \mathrm{~cm}$ and $24 \%$ of the germplasm exceeded $7.6 \mathrm{~cm}$

\subsection{Pod Width}

Significant variation in pod width was observed (Table 3). Accessions VF-10 and VF-4 showed the highest pod width $(2.03$ and $2.07 \mathrm{~cm}$ respectively), while VF-3 gave the lowest pod width $(1 \mathrm{~cm})$. Pod width is highly affected by seed size (Al-Rifaee et al., 2004). All the genotypes used in the present study originated from small seeds, so the variation on pod width may be due to pod flesh. 
Table 3. Production characters of of nineteen faba bean landraces grown during 2009/2010 growing season

\begin{tabular}{|c|c|c|c|c|c|c|}
\hline Accession & PL & PW & NPP & TPWP & NSP & SW \\
\hline VF-1 & $4.97^{\mathrm{hi}^{*}}$ & $1.20^{\mathrm{efgh}^{*}}$ & $6.66^{\mathrm{g}^{*}}$ & $45.53^{\mathrm{e}^{*}}$ & $2.23^{\mathrm{hi}^{*}}$ & $92.00^{\mathrm{efg}^{*}}$ \\
\hline $\mathrm{VF}-2$ & $4.47^{\mathrm{i}}$ & $1.03^{\mathrm{jk}}$ & $4.47^{\mathrm{h}}$ & $20.13^{\mathrm{k}}$ & $5.33^{\mathrm{fg}}$ & $41.67^{\mathrm{k}}$ \\
\hline VF-3 & $5.17^{\mathrm{hi}}$ & $1.00^{\mathrm{kl}}$ & $10.53^{\mathrm{e}}$ & $30.53^{\mathrm{ij}}$ & $6.07^{\mathrm{de}}$ & $82.67^{\mathrm{fgh}}$ \\
\hline VF-4 & $11.17^{\mathrm{a}}$ & $2.07^{\mathrm{a}}$ & $16.27^{\mathrm{c}}$ & $91.67^{\mathrm{a}}$ & $7.27^{\mathrm{c}}$ & $239.00^{\mathrm{a}}$ \\
\hline VF-5 & $9.43^{\mathrm{b}}$ & $1.67^{\mathrm{b}}$ & $16.33^{\mathrm{c}}$ & $41.60^{\mathrm{fg}}$ & $7.20^{\mathrm{c}}$ & $165.33^{\mathrm{b}}$ \\
\hline VF-6 & $7.10^{\mathrm{d}}$ & $1.27^{\mathrm{def}}$ & $16.33^{\mathrm{c}}$ & $32.87^{\mathrm{hi}}$ & $6.93^{\mathrm{c}}$ & $105.67^{\mathrm{e}}$ \\
\hline VF-7 & $5.10^{\mathrm{hi}}$ & $1.07^{\mathrm{ijk}}$ & $2.67^{\mathrm{i}}$ & $20.00^{\mathrm{k}}$ & $4.00^{\mathrm{ij}}$ & $60.00^{\mathrm{j}}$ \\
\hline VF-8 & $5.07^{\mathrm{hi}}$ & $1.17^{\mathrm{fghi}}$ & $11.00^{\mathrm{de}}$ & $38.87^{\mathrm{g}}$ & $6.27^{\mathrm{d}}$ & $95.67^{\mathrm{ef}}$ \\
\hline VF-9 & $8.63^{\mathrm{c}}$ & $1.33^{\mathrm{d}}$ & $10.53^{\mathrm{e}}$ & $49.40^{\mathrm{d}}$ & $8.00^{\mathrm{b}}$ & $143.00^{\mathrm{c}}$ \\
\hline VF-10 & $11.47^{\mathrm{a}}$ & $2.03^{\mathrm{a}}$ & $16.60^{\mathrm{c}}$ & $63.80^{\mathrm{c}}$ & $8.93^{\mathrm{a}}$ & $175.67^{\mathrm{b}}$ \\
\hline VF-11 & $6.27^{\mathrm{ef}}$ & $1.23^{\mathrm{defg}}$ & $12.13^{\mathrm{d}}$ & $48.87^{\mathrm{d}}$ & $5.40^{\mathrm{fg}}$ & $121.00^{\mathrm{d}}$ \\
\hline VF-12 & $5.97^{\mathrm{efg}}$ & $1.10^{\mathrm{hijk}}$ & $10.53^{\mathrm{e}}$ & $31.67^{\mathrm{hi}}$ & $6.20^{\mathrm{d}}$ & $79.33^{\text {ghi }}$ \\
\hline VF-13 & $6.67^{\mathrm{de}}$ & $1.10^{\mathrm{hijk}}$ & $25.53^{\mathrm{a}}$ & $43.87^{\mathrm{ef}}$ & $3.60^{\mathrm{j}}$ & $123.33^{\mathrm{d}}$ \\
\hline VF-14 & $5.40^{\mathrm{gh}}$ & $1.20^{\text {efgh }}$ & $10.93^{\mathrm{de}}$ & $33.73^{\mathrm{h}}$ & $5.67^{\mathrm{def}}$ & $77.67^{\text {ghi }}$ \\
\hline VF-15 & $5.17^{\mathrm{hi}}$ & $1.03^{\mathrm{jk}}$ & $15.80^{\mathrm{c}}$ & $67.40^{\mathrm{b}}$ & $5.53^{\mathrm{efg}}$ & $64.67^{\mathrm{ij}}$ \\
\hline VF-16 & $6.17^{\mathrm{efg}}$ & $1.30^{\mathrm{de}}$ & $19.93^{\mathrm{b}}$ & $46.93^{\mathrm{de}}$ & $5.33^{\mathrm{fg}}$ & $127.00^{\mathrm{d}}$ \\
\hline VF-17 & $6.07^{\mathrm{efg}}$ & $0.90^{1}$ & $3.00^{\mathrm{i}}$ & $20.53^{\mathrm{k}}$ & $5.07^{\mathrm{fg}}$ & $35.67^{\mathrm{k}}$ \\
\hline VF-18 & $5.50^{\mathrm{fgh}}$ & $1.13^{\text {ghij }}$ & $9.07^{\mathrm{f}}$ & $27.80^{\mathrm{j}}$ & $4.93^{\mathrm{gh}}$ & $104.00^{\mathrm{e}}$ \\
\hline VF-19 & $5.50^{\mathrm{fgh}}$ & $1.53^{\mathrm{c}}$ & $2.33^{\mathrm{i}}$ & 17.40 & $4.27^{\mathrm{i}}$ & $72.00 \mathrm{l}^{\mathrm{hij}}$ \\
\hline
\end{tabular}

${ }^{*}$ Means in the same column with similar letters are not significantly different (REGWQ, $\mathrm{P} \geq 0.05$ ).

PL: Pod length $(\mathrm{cm})$, PW: pod width $(\mathrm{cm})$, NPP: no. of pods per plant, TPWP: total pods weight per plant(gm), NSP: Number of seeds per pod, SW: 100 seed weight.

\subsection{Number of Pods per Plant}

Significant variation in pods number per plant was observed (Table 3). Accession VF-13 gave significantly the highest average pod number per plant (25.53 pods). Accessions VF-19, VF-7 and VF-17 gave the lowest average number of pods per plant $(2.33,2.67$ and 3 pods respectively). These results agree with the results reported by Hassan and Ishaq, (1972), who found that genotypes varied in their pod number per plant. Pilbeam et al. (1992) reported that pod number per plant in Ticol faba bean variety was greater than Minica variety during two growing seasons.

\subsection{Total Pod Weight per Plant}

Significant variation in total pod weight per plant was observed (Table 3). Accession VF-4 significantly gave the highest pod weight per plant (91.67 gm). Accessions VF-19, VF-7, VF-2 and VF-17 significantly gave the lowest pod weight per plant (17.40, 20, 20.13 and 20.53 gm respectively).The variation on total pod weight per plant was due to the total number of pods per plant and not due to seed size since all the genotypes originated from small seeds. These results are in agreement with Della (1988), who found significant differences in pod weight

\subsection{Number of Seeds per Pod}

Significant variation in number of seeds per pod was observed (Table 3). Accession VF-10 significantly had the highest average seed number per pod (8.93 seeds) while VF-7 and VF-19 significantly showed the lowest average seed number per pod (4 and 4.27 seeds respectively). Suso et al. (1996) reported significant differences in seed number per pod among twelve faba bean genotypes. Li-juan et al. (1993) reported that number of seeds per pod ranged from 1.7 to 2.9 in a collection of 1500 accessions from different provinces in China. Abdelmola 
and Abuanja (2007) reported that number of seeds per pod was more influenced by genetic than environmental factors.

\subsection{One Hundred-Seed Weight}

Significant variation in 100-seed weight was observed (Table 3). Accession VF-4 gave significantly the highest 100 -seed weight $(239 \mathrm{gm})$ while VF-17 and VF-2 gave the lowest 100-seed weight (35.67 and $41.67 \mathrm{gm}$ respectively). These results were in agreement with Della (1988) who found that seeds weight varied considerably among the genotypes.

\subsection{Correlation between the Studied Agronomic Traits}

Pearson correlation coefficients between the studied characters were computed and presented in Table 4 . The highest positive significant correlations were found between 100-seed weight and pod length (0.879), followed by 100 -seed weight and pod weight $(0.851)$, and between pod width and pod length (0.874). Pod length with number of seeds per pod and total pod weight per plant with 100-seed weight were also highly correlated $(0.756$ and 0.779 , respectively). These results reflected the importance of pod width, pod length, 100 -seed weight and total number of pods per plant in the determination of pod weight in faba bean. Sprent et al. (1977) reported that the major factor affecting yield is the number of pods per plant which reach maturity.

Table 4. Correlation coefficients for six agronomic characters of nineteen faba bean landraces grown during 2009/2010

\begin{tabular}{llllll}
\hline & $\mathbf{N P P}^{1}$ & $\mathbf{N S P}^{1}$ & $\mathbf{P L}^{1}$ & $\mathbf{P W}^{1}$ & $\mathbf{S W}^{1}$ \\
\hline NSP & $0.283^{\text {ns }}$ & & & \\
PL & $0.465^{*}$ & $0.756^{* * *}$ & & \\
PW & $0.321^{\mathrm{ns}}$ & $0.622^{* *}$ & $0.874^{* * *}$ & & \\
SW & $0.608^{* *}$ & $0.604^{* *}$ & $0.879^{* * *}$ & $0.851^{* * *}$ & \\
TPWP & $0.609^{* *}$ & $0.500^{* *}$ & $0.666^{* * *}$ & $0.628^{* *}$ & $0.779^{* * *}$
\end{tabular}

${ }^{1}$ NPP: Number of pods per plant; NSP: Number of seeds per pod; PL: Pod length; PW: Pod width; SW: 100 seed weight; TPWP: Total pod weight per plant.

$* * *, * *$ and $*$ significant at $\mathrm{p} \leq 0.001, \mathrm{p} \leq 0,01$ and $\mathrm{p} \leq 0.05$, respectively.

\subsection{Genetic Similarities among Genotypes}

Cluster analysis was used to further investigate the inter-relationships of the accessions using six agronomic traits (pod length, pod width, number of pods per plant, number of seeds per pod, 100-seed weight and total pod weight per plant). The accessions were grouped into two main clusters (A and B). Each of the main clusters was divided into two sub clusters (Figure 1). More than half of the accessions (53.6\%) were grouped in the same cluster (cluster A), and the rest of the accessions were grouped in the other cluster (B). It is clear that accessions VF-4 and VF-10, VF-5 and VF-9 are related to each other and are far from the rest of the collection. 


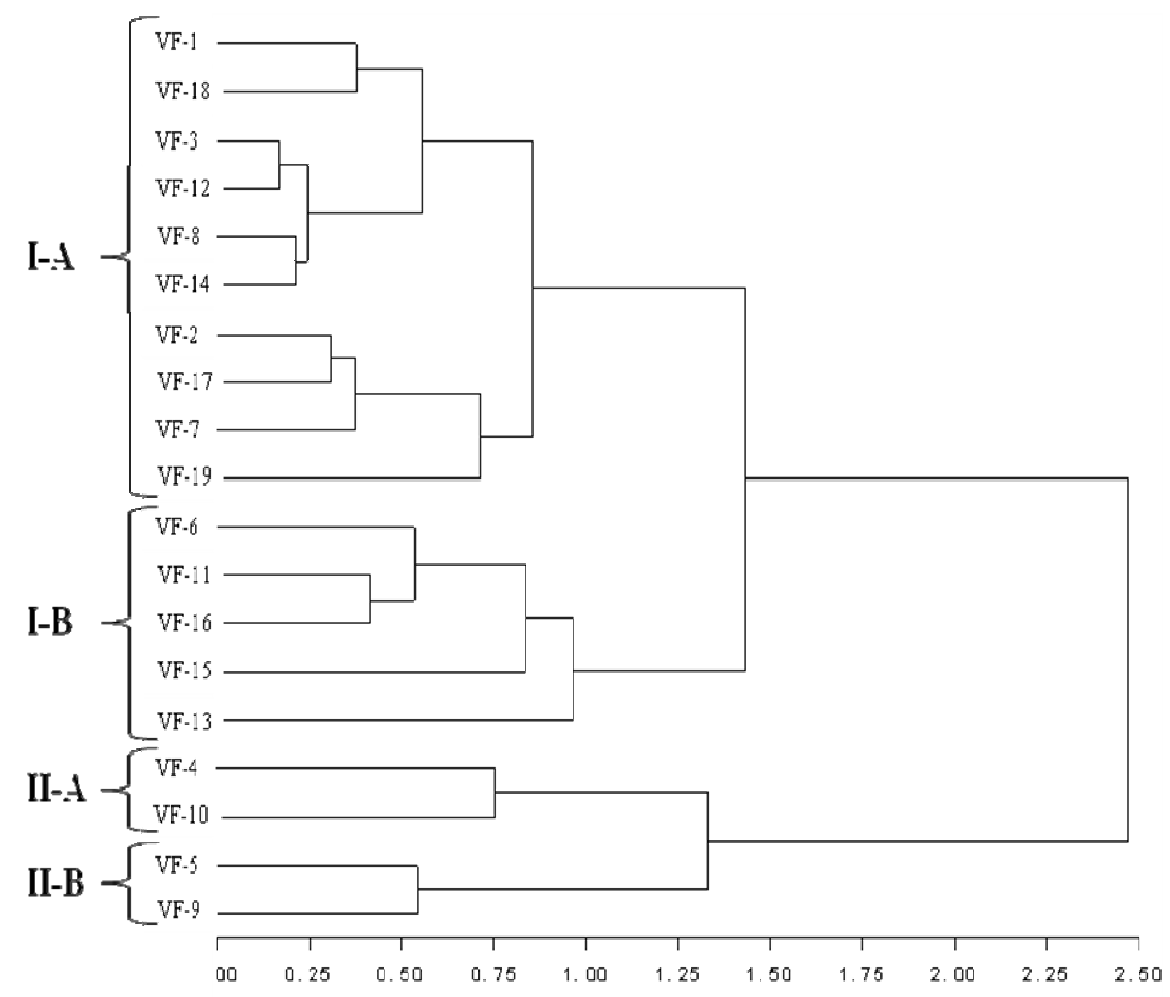

Figure 1. Cluster analysis showing the relationships among faba bean accessions determined on the basis of six yield traits

\section{Acknowledgements}

The author gratefully acknowledges Mr. Omar Abo Baker for technical help and An-Najah National University for financial support.

\section{References}

Abedlmula, A. A., \& Abuanja, I. K. (2007). Genotypic responses, yield stability, and association between characters among some of Sudanese faba bean (Vicia faba L.) genotypes under heat stress. International Agricultural Research for Development, 1-7.

AL-Refaee, M., Turk, M., \& Tawaha, A. (2004). Effect of seed size and plant population density on yield and yield components of local faba bean (Vicia faba L. Major). International Journal of Agriculture and Biology, 2, 294-299.

Ceccarelli, S., Grand, S., \& Vanleur, J. A. G. (1987). Genetic diversity in barley landraces from Syria and Jordan. Euphitica, 36, 389-405. http://dx.doi.org/10.1007/BF00041482

Cubero, J. I. (1974). On the evolution of Vicia faba. Theoretical and Applied Genetics, 45, 47-51. http://dx.doi.org/10.1007/BF00283475

Della, A. (1988). Characteristics and variation of Cyprus faba bean germplasm, FABIS Newsletter, 21, 9-12.

FAOSTAT. (2009). Food and Agriculture Organization. Retrieved from http://faostat.fao.org/site/567/default.aspx\#ancor

Gous, R. M. (2011). Evaluation of faba bean (Vicia faba cv. Fiord) as a protein source for broilers. South African Journal of Animal Science, 41, 71-78

Hassan, M., \& Ishag, S. (1972). Physiology of yield in field beans (Vicia faba L.) I. Yield and Yield component. Journal of Agricultural Science, 79, 181-189.

Li-juan, L., Zhao-hai, Y., Zhao-jie, Z., Ming-shi, X., \& Han-qing Y. (1993). Study and utilization of faba bean germplasm resources. In M. C. Saxena, S. Weigand, \& L. Li-Juan (Eds.), Faba Bean in China: State-of-the Art Review (pp. 51-63). ICARDA Press, (Ch. 4). 
Nanda, H. C., Yasin, M., Singh, C. B., \& Rao, S. K. (1988). Effect of water stress on dry matter production, harves index, seed yield and its components in faba bean (Vicia faba L.). FABIS Newsletter, 21, 26-30.

PCBS. (2008) Palestinian Central Bureau of Statistics, Ramallah, Palestine. Retrieved from http://www.pcbs.gov.ps/DesktopDefault.aspx?tabID=3758\&lang=ar-JO

Pilbeam, C. J., Aktase, J. K., Hebblethwaite, P. D., \& Wright, S. D. (1992). Yield production in two contrasting form of spring-sown faba bean in relation to water supply. Field Crops Research, 29, 273-287. http://dx.doi.org/10.1016/0378-4290(92)90030-D

Polignano, G. B., Uggenti, P., \& Scippa, G. (1993). The pattern of genetic diversity in faba bean collections from Ethiopia and Afghanistan. Genetic Resources and Crop Evolution, 40, 71-75. http://dx.doi.org/10.1007/BF00052637

Reiter, K., Schmidtke, K., \& Rauber, R. (2002) The influence of long-term tillage systems on symbiotic N2 fixation of pea (Pisum sativum L.) and red clover (Trifolium pratense L.). Plant and Soil, 238, 41-55. http://dx.doi.org/10.1023/A:1014240311597

Salem, K. F. M., El-Zanaty, A. M., \& Esmail, R. M. (2008). Assessing wheat (Triticum aestivum L.) genetic diversity using morphological characters and microsatallite markers. World Journal of Agricultural Sciences, 4, 538-544

SAS Institute. (2002). SAS/STAT Software, Release 9.0. SAS Ins, Cary, N.C.

Silim, S. N., \& Saxena, M. C. (1992). Comparative performance of some faba bean (Vicia faba L.) cultivars of contrasting plant types. 2. Growth and development in relation to yield. Journal of Agricultural Science 118, 333-342. http://dx.doi.org/10.1017/S0021859600070702

Sprent, J. I., Bradfort, A. M., \& Norton, C. (1977). Seasonal growth patterns in field beans as affected by population density shading and its relationship with soil moisture. Journal of Agricultural Science, 88, 293-301. http://dx.doi.org/10.1017/S0021859600034791

Suso, M. J., Moreno, M. T., \& Cubero, J. I. (1993). New isozyme markers in Vicia faba: inheritance and linkage. Plant Breeding, 40, 105-111.

Suso, M. J., Moreno, M. T., Mondragao-Rodrigues, F., \& Cubero, J. I. (1996). Reproducive biology of Vicia faba: Role of pollination conditions. Field Crops Research, 46, 81-91. http://dx.doi.org/10.1016/0378-4290(95)00089-5

Terzopoulos, P. J., Kaltsikes, P. J., \& Bebeli, P. J. (2003). Collection, evaluation and classification of Greek populations of faba bean (Vicia faba L.). Genetic Resources and Crop Evolution, 50, 373-381. http://dx.doi.org/10.1023/A:1023962618319 